\title{
REGIONAL AND SEASONAL DIET OF THE WESTERN BURROWING OWL IN SOUTH CENTRAL NEVADA
}

\author{
Derek B. Hall1,3, Paul D. Greger ${ }^{1}$, and Jeffrey R. Rosier ${ }^{2,4}$
}

\begin{abstract}
We examined diets of Western Burrowing Owls (Athene cunicularia hypugaea) based on contents of pellets and large prey remains collected year-round at burrows in each of the 3 regions in south central Nevada (Mojave Desert, Great Basin Desert, and Transition region). The most common prey items, based on percent frequency of occurrence, were crickets and grasshoppers, beetles, rodents, sun spiders, and scorpions. The most common vertebrate prey was kangaroo rats (Dipodomys spp.). True bugs (Hemiptera), scorpions, and western harvest mice (Reithrodontomys megalotis) occurred most frequently in pellets from the Great Basin Desert region. Kangaroo rats (Dipodomys spp.) and pocket mice (Perognathinae) were the most important vertebrate prey items in the Transition and Mojave Desert regions, respectively. Frequency of occurrence of any invertebrate prey was high $(>80 \%)$ in samples year-round but dropped in winter samples, with scorpions and sun spiders exhibiting the steepest declines. Frequency of occurrence of any vertebrate prey peaked in spring samples, was intermediate for winter and summer samples, and was lowest in fall samples. With the possible exception of selecting for western harvest mice in the Great Basin Desert region, Western Burrowing Owls in our study appeared to be opportunistic foragers with a generalist feeding strategy.
\end{abstract}

Key words: Athene cunicularia hypugaea, Western Burrowing Owl, diet, Great Basin Desert, Mojave Desert, prey selection.

DOE/NV/25946-203

The Western Burrowing Owl (Athene cunicularia hypugaea) is declining throughout much of its range and is currently considered a national bird of conservation concern by the U.S. Fish and Wildlife Service (Klute et al. 2003). Knowledge of the Burrowing Owl's diet is important for the conservation of this species because it enables managers to evaluate how land management activities influence prey that are most important to the owl. While many researchers have investigated the diet of the Burrowing Owl (Maser et al. 1971, Smith and Murphy 1973, Gleason and Craig 1979, Barrows 1989, Green et al. 1993, Haug et al. 1993, Plumpton and Lutz 1993, York et al. 2002, Rosenberg and Haley 2004, Moulton et al. 2005), few have conducted studies in arid desert regions (Glover 1953, Brown et al. 1986, Barrows 1989). Additionally, we are aware of only 4 studies in which investigators examined the year-round diet of the Burrowing Owl (Maser et al. 1971, Thomsen 1971, Butts 1973, Tyler 1983). Herein we examine year-round diets of
Burrowing Owls in 3 different regions in south central Nevada.

\section{STUdy AREA}

Our 3 study areas were located on the Nevada Test Site (NTS), a $3561-\mathrm{km}^{2}$ area in south central Nevada administered by the U.S. Department of Energy, National Nuclear Security Administration (Fig. 1). Despite drastic changes to localized areas of the NTS due to nuclear testing activities, approximately $93 \%$ of the NTS remains relatively pristine and undisturbed (U.S. Department of Energy 1996). The NTS has a climate characteristic of high deserts, with little precipitation, hot summers, mild winters, and high circadian variation in temperature ranges. Monthly average temperatures range from $7{ }^{\circ} \mathrm{C}$ in January to $32{ }^{\circ} \mathrm{C}$ in July, and average annual precipitation ranges from $15 \mathrm{~cm}$ at the low elevations to $23 \mathrm{~cm}$ at the high elevations (U.S. Department of Energy 1996). Most precipitation occurs from

\footnotetext{
${ }^{1}$ National Security Technologies, LLC, M/S NTS260, Box 98521, Las Vegas, NV 89193.

${ }^{2}$ Department of Fisheries and Wildlife, Oregon State University, Corvallis, OR 97331-3803.

${ }^{3}$ E-mail: halldb@nv.doe.gov

${ }^{4}$ Present address: Bureau of Land Management, Grants Pass, OR 97526.
} 


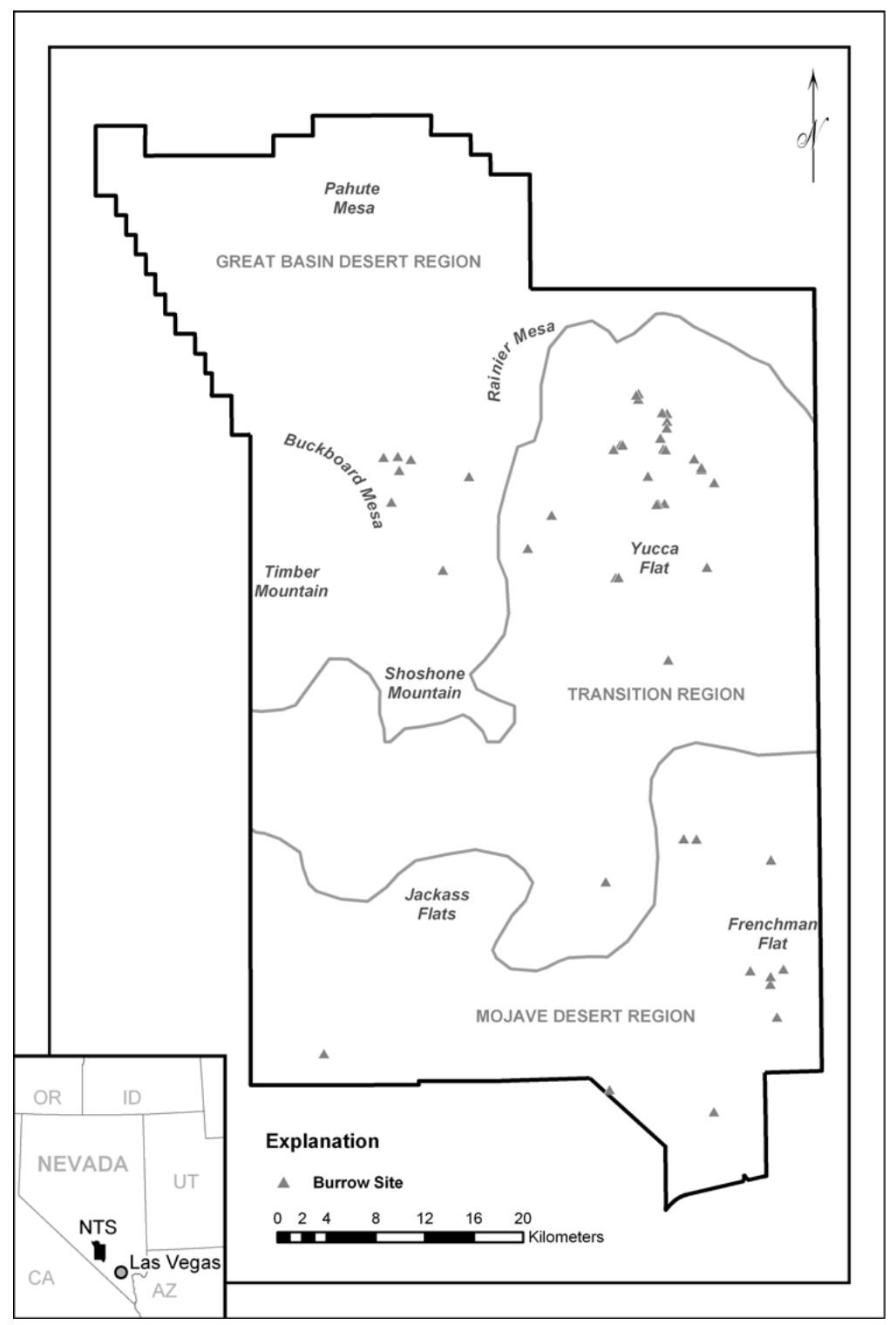

Fig. 1. Geographic location, regional boundaries, and Western Burrowing Owl diet sampling locations on the Nevada Test Site, south central Nevada (see inset).

December to March in the form of rain or snow, with less rain occurring in July and August. Elevations on the NTS range from $823 \mathrm{~m}$ to $2341 \mathrm{~m}$ above sea level.

The NTS is located in an area of southern Nevada that lies between the Great Basin Desert and the Mojave Desert as defined by Jaeger (1957). Transitional areas between the 2 deserts are also present, having been created by gradients in precipitation, elevation, tem- perature, and soils. Based on differences in climate and vegetation, Ostler et al. (2000) recognized 3 distinct vegetation regions on the NTS: the Great Basin Desert, Mojave Desert, and Transition regions (Fig. 1). The Great Basin Desert is a comparatively cold desert with dominant plant species consisting of sagebrush species (Artemisia spp.), singleleaf pinyon (Pinus monophylla), and Utah juniper (Juniperus osteosperma). The Mojave 
TABLE 1. Percent (\%) frequency of occurrence of prey items by region and all regions combined, 1997-2000 $(n=$ number of samples with numbers of pellets in parentheses).

\begin{tabular}{|c|c|c|c|c|}
\hline Taxon & $\begin{array}{c}\text { Great Basin } \\
n=58(339)\end{array}$ & $\begin{array}{c}\text { Mojave } \\
n=43(162)\end{array}$ & $\begin{array}{c}\text { Transition } \\
n=191(1130)\end{array}$ & $\begin{array}{c}\text { Regions combined } \\
n=292(1631)\end{array}$ \\
\hline \multicolumn{5}{|l|}{ Invertebrates } \\
\hline \multicolumn{5}{|l|}{ Insects } \\
\hline Crickets / grasshoppers & 79 & 95 & 86 & 86 \\
\hline Beetles & 86 & 72 & 82 & 82 \\
\hline True bugs & 29 & 0 & 4 & 8 \\
\hline \multicolumn{5}{|l|}{ Arachnids } \\
\hline Spiders & 21 & 16 & 26 & 23 \\
\hline Scorpions & 78 & 58 & 46 & 54 \\
\hline Sun spiders (wind scorpions) & 76 & 77 & 61 & 66 \\
\hline Centipedes & 2 & 0 & 1 & 1 \\
\hline Any invertebrate & 93 & 95 & 96 & 95 \\
\hline \multicolumn{5}{|l|}{ Vertebrates } \\
\hline Reptiles & 28 & 16 & 7 & 13 \\
\hline Birds & 0 & 7 & 6 & 5 \\
\hline \multicolumn{5}{|l|}{ Mammals } \\
\hline Shrews & 2 & 0 & 1 & 1 \\
\hline Pocket mice & 7 & 40 & 16 & 18 \\
\hline Kangaroo mice & 0 & 0 & 4 & 3 \\
\hline Kangaroo rats & 26 & 16 & 40 & 34 \\
\hline Thomomys bottae & 3 & 12 & 13 & 11 \\
\hline Reithrodontomys megalotis & 35 & 0 & 6 & 11 \\
\hline White-footed mice & 28 & 9 & 12 & 14 \\
\hline Lemmiscus curtatus & 0 & 0 & 2 & 1 \\
\hline Unidentified rodents & 38 & 26 & 26 & 28 \\
\hline Rabbit & 2 & 0 & 1 & 1 \\
\hline Any rodent & 74 & 63 & 59 & 63 \\
\hline Any vertebrate & 79 & 70 & 62 & 67 \\
\hline
\end{tabular}

Desert is a hot desert, with dominant plant species being creosote bush (Larrea tridentata) and white bursage (Ambrosia dumosa). The Transition region is transitional between the Great Basin and Mojave Desert regions, with dominant plant species consisting of blackbrush (Coleogyne ramosissima), Nevada jointfir (Ephedra nevadensis), and burrobrush (Hymenoclea salsola).

\section{Methods}

We monitored numerous Burrowing Owl burrow sites in 3 regions of the NTS at least monthly from November 1997 to April 1998 and from November 1998 to July 2000. Not all burrow sites were monitored through the entire time, because new burrow sites were found as the study progressed. Pellets and large prey remains (i.e., no invertebrate parts or small bones) were collected opportunistically when we visited burrow sites, and no attempt was made to collect equal numbers of samples per region or season. Pellets that had crumbled or appeared old, as though they had been cleaned out from the burrow, were not collected. All pellets and prey remains collected from a burrow site on a given date constituted a sample and were placed into a plastic bag and labeled with the date, location, and number of pellets collected.

Pellets were teased apart and analyzed according to methods adapted from Maser and Brodie (1966). We used dichotomous keys (Hall 1995, Verts and Carraway 1998) or comparison with specimens at the Oregon State University museum collection to identify rodents to the lowest taxon possible. The same person analyzed all pellets to ensure consistency in identification. Unidentifiable rodent fragments were placed into a separate category called "unidentified rodents." All other vertebrates and invertebrates were identified to order or class. For seasonal analysis, we subdivided the samples into 4 seasonal periods as follows: fall, September-November; winter, DecemberFebruary; spring, March-May; and summer, June-August. Percent frequency of occurrence for each taxon was calculated for each ecoregion and season by dividing the number of samples with a given taxon present in the sample by the total number of samples for a given 
TABLE 2. Percent (\%) frequency of occurrence of prey items by season, 1997-2000 $(n=$ number of samples with numbers of pellets in parentheses).

\begin{tabular}{|c|c|c|c|c|}
\hline Taxon & $\begin{array}{l}\text { Fall (Sep-Nov) } \\
n=41(213)\end{array}$ & $\begin{array}{c}\text { Winter (Dec-Feb) } \\
n=66(186)\end{array}$ & $\begin{array}{c}\text { Spring (Mar-May) } \\
n=117(806)\end{array}$ & $\begin{array}{c}\text { Summer } \\
\text { (Jun-Aug) } \\
n=68(426)\end{array}$ \\
\hline \multicolumn{5}{|l|}{ Invertebrates } \\
\hline \multicolumn{5}{|l|}{ Insects } \\
\hline Crickets / grasshoppers & 95 & 70 & 88 & 93 \\
\hline Beetles & 93 & 74 & 86 & 77 \\
\hline True bugs & 5 & 0 & 12 & 12 \\
\hline \multicolumn{5}{|l|}{ Arachnids } \\
\hline Spiders & 24 & 15 & 27 & 24 \\
\hline Scorpions & 63 & 20 & 58 & 75 \\
\hline Sun spiders (wind scorpions) & 73 & 33 & 70 & 87 \\
\hline Centipedes & 0 & 0 & 2 & 0 \\
\hline Any invertebrate & 100 & 83 & 99 & 97 \\
\hline \multicolumn{5}{|l|}{ Vertebrates } \\
\hline Reptiles & 0 & 0 & 16 & 27 \\
\hline Birds & 10 & 6 & 4 & 2 \\
\hline \multicolumn{5}{|l|}{ Mammals } \\
\hline Shrews & 0 & 0 & 1 & 2 \\
\hline Pocket mice & 2 & 15 & 27 & 13 \\
\hline Kangaroo mice & 0 & 5 & 3 & 3 \\
\hline Kangaroo rats & 10 & 24 & 50 & 29 \\
\hline Thomomys bottae & 0 & 0 & 17 & 16 \\
\hline Reithrodontomys megalotis & 5 & 15 & 13 & 7 \\
\hline White-footed mice & 2 & 21 & 14 & 16 \\
\hline Lemmiscus curtatus & 0 & 0 & 1 & 3 \\
\hline Unidentified rodents & 20 & 33 & 30 & 25 \\
\hline Rabbit & 0 & 0 & 1 & 0 \\
\hline Any rodent & 27 & 62 & 76 & 62 \\
\hline Any vertebrate & 34 & 67 & 79 & 66 \\
\hline
\end{tabular}

ecoregion or season and multiplying the quotient by 100 .

\section{Results}

A total of 292 samples consisting of 1631 pellets were collected from 29 burrow sites in the Transition region, 7 in the Great Basin Desert region, and 11 in the Mojave Desert region of the NTS (Fig. 1). The average number of pellets per sample was $5.6(s=5.8$, range $1-38)$. We identified 7 taxa of invertebrates and 11 taxa of vertebrates. We also designated a category for unidentified rodents (Table 1). Most prey items were found in pellets. Fifteen prey remains were collected, and only 10 of these were identified. They included a pocket gopher skull, 2 kangaroo rat tails, 2 rodent tails, a rabbit foot, a snake, 2 beetles, and a centipede.

Across all regions, crickets and grasshoppers (Orthoptera), beetles (Coleoptera), sun spiders (Solpugida), rodents, and scorpions were the most common prey items found, each occurring in more than half of the samples. Kangaroo rats (Dipodomys spp.) were the most common rodent found in the samples (Table 1). The data also reveal important differences in food habits among ecoregions, with percent frequency of occurrence for true bugs (Hemiptera), scorpions, and western harvest mice (Reithrodontomys megalotis) being higher in the Great Basin Desert region than in the Transition or Mojave Desert regions. Pocket mice (Perognathinae) and kangaroo rats are the most important vertebrate prey items in the Mojave Desert and Transition regions, respectively, while kangaroo rats, western harvest mice, and white-footed mice (Peromyscus spp.) were all important prey items in the Great Basin Desert region (Table 1).

Based on the number of taxa, the diet was most diverse in the Transition region (19 taxa) and least diverse in the Mojave Desert (12 taxa). True bugs, centipedes (Chilopoda), shrews (Soricidae), kangaroo mice (Microdipodops spp.), western harvest mice, sagebrush voles (Lemmiscus curtatus), and rabbits (Lagomorpha) were absent in samples from the Mojave Desert region, while birds, kangaroo mice, 
and sagebrush voles were absent in samples from the Great Basin Desert (Table 1).

Frequency of occurrence of any invertebrate prey was high $(>80 \%)$ in samples year-round but dropped in winter samples, with scorpions and sun spiders exhibiting the steepest declines. Frequency of occurrence of any vertebrate prey peaked in spring samples, was intermediate for winter and summer samples, and was lowest in fall samples. Frequency of occurrence of kangaroo rats peaked during spring. Reptiles, shrews, Botta's pocket gophers (Thomomys bottae), and sagebrush voles were not detected in samples collected during fall or winter but were detected in samples collected during spring and summer (Table 2).

\section{Discussion}

Diets of Burrowing Owls on the NTS were similar to diets of Burrowing Owls in other parts of their range except that sun spiders, which are a dominant prey item on the NTS, are less common in diets elsewhere. Only Gleason and Craig (1979), Green et al. (1993), Rosenberg and Haley (2004), York et al. (2002), and Moulton et al. (2005) documented sun spiders as prey items, and none of these reported frequency values for sun spiders as high as the values in our study. Bond (1942) found that spadefoot toads (Scaphiopus intermontana) were a dominant prey item in 12 pellets collected in western Nevada, with lesser amounts of insects (mainly beetles and ants), as well as rodents, a snake, a rabbit, and a scorpion. Spadefoot toads are not known to occur on the NTS (Wills and Ostler 2001), and none were found in our samples. The taxa in our samples from the Mojave Desert were similar to those in samples collected in the Colorado Desert by Barrows (1989), but the frequency of occurrence of individual taxa was usually higher in our samples than in Barrows' samples. For example, Barrows $(1989: 8)$ detected scorpions in 6\%, rodents in $31 \%$, and invertebrates in $67 \%$ of his samples, whereas we detected these in $58 \%, 63 \%$, and $95 \%$ of our samples, respectively.

Owl diets often differ greatly both within and among regions, depending on local and regional variation in the abundance and distribution of different types of prey (Marti 1974, Forsman et al. 2004). Although we did not collect data on prey abundance in our study areas, previous trapping studies near our study area indi- cated that the number of rodent species was higher in the Great Basin Desert than in the Mojave Desert and Transition regions (Bradley and Moor 1978, Moor and Bradley 1985). This could explain why, in our study, Burrowing Owls in the Great Basin Desert utilized a broader range of rodent prey than owls in the Mojave Desert or Transition region. Also, the list of rodent species taken by owls in our study was the same as the list of rodents captured in the earlier trapping studies except that western harvest mice, which occurred in $35 \%$ of samples from the Great Basin Desert region, were not captured in the trapping studies (Bradley and Moor 1978, Moor and Bradley 1985). Possible explanations include a marked increase in the abundance of western harvest mice in this area during the time of our study compared to other studies or a potential preference by the Burrowing Owls for this prey item. Small mammal trapping near Burrowing Owl burrows in the Great Basin Desert region during 2006 detected 1 western harvest mouse out of 169 captures $(0.6 \%)$ suggesting that this species is not abundant in this region or that it may just be difficult to capture. However, small mammal trapping in other areas of the NTS during 2006 resulted in several captures of western harvest mice, particularly around water sources (National Security Technologies LLC 2007), which do not occur near (i.e., $<5.0 \mathrm{~km}$ from) Burrowing Owl burrows. In contrast to our findings, Maser et al. (1971) documented few western harvest mice in pellets from Oregon, even though harvest mice were relatively common in their study area. They hypothesized that the small size of the mouse, its quick movements, and its affinity to cover would make them difficult to capture.

During an 8-year period (1987-1994), Saethre (1995) found that Merriam's kangaroo rat (Dipodomys merriami) was the most abundant rodent on disturbed areas in the Transition region. Most of the burrow sites where samples were collected in the Transition region were on disturbed sites. This suggests that the prevalence of kangaroo rats in diets of Burrowing Owls in samples from the Transition region reflects an opportunistic response to prey abundance as opposed to selection for a certain rodent species.

In our study, invertebrates were a very frequent part of the Burrowing Owl diet in all 
regions and seasons, with lower values during winter than during other seasons. This pattern follows the pattern of relative availability of most invertebrates, which is generally lowest during the colder winter months. Barnum (1964) determined that crickets and grasshoppers on the NTS were found mostly during March through November. Gertsch and Allred (1965) studied scorpions on the NTS and found that they were nocturnal and most active between June and September with the highest population peaks in July and August. Similarly, our data show a pattern of high occurrence of scorpions in samples collected during summer, intermediate occurrence in fall and spring, and lowest occurrence in winter. Muma (1963) studied sun spiders on the NTS and determined that they were nocturnal, cursorial predators and that most adults were collected during spring and summer. In our samples, the frequency of occurrence of sun spiders was highest in summer, intermediate in fall and spring, and lowest in winter.

On the NTS, vertebrates occurred less frequently in samples than invertebrates did, but because of their greater biomass, vertebrates are likely the most important component of the Burrowing Owl diet. In a study of foraging behaviors of nesting Burrowing Owls in Saskatchewan, Canada, Poulin and Todd (2006) found that despite overwhelming numbers of insects being captured, $>90 \%$ of the prey biomass was from vertebrates. Kangaroo rats appear to be especially important prey during the spring when Burrowing Owls on our study area are reproducing. In fact, the frequency of occurrence of any vertebrate peaks in spring, which may be due to increased vertebrate availability (e.g., young rodents) or increased energetic demands of reproducing owls. Why vertebrate values drop so low during fall is not clearly understood. Reduced reptile activity partially explains the drop, but other factors (e.g., hunting proficiency of recently fledged young, decreased energetic demands of nonreproductive owls) are probably involved as well.

Based on the activity patterns of their dominant prey, Burrowing Owls on the NTS forage primarily for insects during the day and for rodents, sun spiders, and scorpions between dusk and dawn. Activity data and photographs taken with TrailMaster ${ }^{\circledR}$ camera systems (Hall et al. 2003) confirm prey deliveries throughout the night. Likewise, Marti (1974) observed Burrowing Owls capturing only insects during daylight hours and suggested that most vertebrates must have been captured when light levels were low. Haug and Oliphant (1990) observed Burrowing Owls foraging for insects during the day but never saw them foraging for or carrying small mammals during the day. Poulin and Todd (2006) used infrared cameras to record prey deliveries and concluded that "insects were consistently delivered at the highest rate during the day and vertebrates were consistently delivered at the highest rates during the dusk and dawn periods."

Numerous researchers (e.g., Coulombe 1971, Thomsen 1971, Haug 1985, MacCracken et al. 1985, Plumpton and Lutz 1993, and York et al. 2002) have pointed out that pellet analysis does not always provide a true picture of everything Burrowing Owls eat, because prey are consumed and digested differently, pellets decompose at different rates, and age- or sexbased differences in foraging may bias pellet analysis results. Thus, some prey items may be missed or undercounted, especially soft items that are completely digested. Grant (1965) observed Burrowing Owls catching at least as many amphibians as mammals, but he only found mammal remains in pellets. Plumpton and Lutz (1993) suggest that, in addition to pellets, prey items found at burrows should be documented to give a truer picture of Burrowing Owl diet. We collected and analyzed both pellets and large prey remains, and we recognize that some prey items may have been missed, especially small species that are difficult to see. More thorough collections of prey remains, including invertebrate parts and small bones, may have added additional prey items and probably would have changed frequency values for some prey items. Several times we noticed scorpion tails or sun spider parts on the burrow apron, but we did not collect them. Relatively new techniques such as remote videography (Lewis et al. 2004) or infrared cameras (Poulin and Todd 2006) have been used to describe prey deliveries to northern goshawk (Accipiter gentilis) and Burrowing Owl nests, respectively. However, more studies are needed to compare results from Burrowing Owl diets determined from indirect methods (i.e., pellet analysis, collections of prey remains) and direct methods (i.e., video monitoring, visual observations at nests) to 
evaluate the accuracy and cost-effectiveness of each method.

We thank J.L. Bishop and K. Kaumans for help with data collection and entry; C. Davis, M.R. Riggs, and J.H. Reynolds for providing invaluable statistical advice; A. Cushman for producing the GIS figure; and D. Rosenberg for providing administrative support. We also thank H. Gang, J. Jablonski, C. Gerlach, N. Ronan, C. Moulton, E. Forsman, and an anonymous reviewer for helpful reviews of the manuscript.

This manuscript was authored by National Security Technologies, LLC, under Contract No. DE-AC52-06 NA25946 with the U.S. Department of Energy. The United States Government retains copyright, and the publisher, by accepting the article for publication, acknowledges that the United States Government retains a nonexclusive, paid-up, irrevocable, worldwide license to publish or reproduce the published form of this manuscript, or allow others to do so, for United States Government.

\section{Literature Cited}

Barnum, A.H. 1964. Orthoptera of the Nevada Test Site. Brigham Young University Science Bulletin, Biological Series 4(3): 1-134.

Barrows, C.W. 1989. Diets of five species of desert owls. Western Birds 20:1-10.

Bond, R.M. 1942. Food of the Burrowing Owl in western Nevada. Condor 44:183.

Bradley, W.G., AND K.S. Moor. 1978. Ecological studies of small mammals in a nuclear site on Nevada Test Site. Pages 1-13 in M.G. White and P.B. Dunaway, editors, Selected environmental plutonium research reports of the NAEG. U.S. Department of Energy Report NVO-192, UC-11, Las Vegas, NV.

Brown, B.A., J.O. Whitaker, T.W. French, and C. Maser. 1986. Note on food habits of the Screech Owl and Burrowing Owl of southeastern Oregon. Great Basin Naturalist 46:421-426.

ButTs, K.O. 1973. Life history and habitat requirements of Burrowing Owls in western Oklahoma. Master's thesis, Oklahoma State University, Stillwater, OK.

Coulombe, H.N. 1971. Biology and population ecology of the Burrowing Owl, Speotyto cunicularia, in the Imperial Valley of California. Condor 73:162-176.

Forsman, E.D., R.G. Anthony, E.C. Meslow, and C.J. ZABEL. 2004. Diets and foraging behavior of Northern Spotted Owls in Oregon. Journal of Raptor Research 38:214-230.

Gertsch, W.J., AND D.M. AlLred. 1965. Scorpions of the Nevada Test Site. Brigham Young University Science Bulletin, Biological Series 6(4):1-15.

Gleason, R.S., and T.H. Craig. 1979. Food habits of Burrowing Owls in southeastern Idaho. Great Basin Naturalist 39:274-276.
GLOver, F.A. 1953. Summer foods of the Burrowing Owl. Condor 55:275.

Grant, R.A. 1965. The Burrowing Owl in Minnesota. Loon 37:2-17.

Green, G.A., R.E. Fitzner, R.G. Anthony, and L.E. Rogers. 1993. Comparative diets of Burrowing Owls in Oregon and Washington. Northwest Science 67: 88-92.

Hall, D.B., P.D. Greger, A.V. Cushman, and C.A. Wills. 2003. Ecology of the Western Burrowing Owl on the Nevada Test Site. U.S. Department of Energy, National Nuclear Security Administration, Nevada Site Office Report DOE/NV/11718_701, Las Vegas, NV.

HaLl, E.R. 1995. Mammals of Nevada. University of Nevada Press, Reno, NV.

Haug, E.A. 1985. Observations on the breeding ecology of Burrowing Owls in Saskatchewan. Master's thesis, University of Saskatchewan, Saskatoon, Saskatchewan, Canada.

Haug, E.A., B.A. Millsap, and M.S. Martell. 1993. Burrowing Owl. The birds of North America, no. 61. Academy of Natural Sciences of Philadelphia, Philadelphia, PA.

HaUg, E.A., AND L.W. OLIPHANT. 1990. Movements, activity patterns and habitat use of Burrowing Owls in Saskatchewan. Journal of Wildlife Management 54: 27-35.

JAEgER, E.C. 1957. The North American deserts. Stanford University Press, Stanford, CA.

Klute, D.S., L.W. Ayers, M.T. Green, W.H. Howe, S.L. Jones, J.A. ShafFer, S.R. ShefField, and T.S. ZimMERMAN. 2003. Status assessment and conservation plan for the Western Burrowing Owl in the United States. U.S. Department of Interior, Fish and Wildlife Service, Biological Technical Publication FWS/BTPR6001-2003, Washington, DC.

Lewis, S.B., M.R. Fuller, AND K. Titus. 2004. A comparison of 3 methods for assessing raptor diet during the breeding season. Wildlife Society Bulletin 32: 373-385.

MacCracken, J.G., D.W. Uresk, and R.M. Hansen. 1985. Burrowing Owl foods in Conata Basin, South Dakota. Great Basin Naturalist 45:287-290.

MaRTI, C.D. 1974. Feeding ecology of four sympatric owls. Condor 76:45-61.

Maser, C., ANd E.D. Brodie, JR. 1966. A study of owl pellet contents from Linn, Benton, and Polk Counties, Oregon. Murrelet 47:9-14.

Maser, C., E.W. Hammer, and S.H. Anderson. 1971. Food habits of the Burrowing Owl in central Oregon. Northwest Science 45:19-26.

Moor, K.S., AND W.G. BRadLEy. 1985. Radioecology of small animal populations inhabiting a nuclear-event site at Nevada Test Site. Pages 321-344 in W.A. Howard and R.G. Fuller, editors, The dynamics of transuranics and other radionuclides in natural environments. U.S. Department of Energy Report NVO272, Las Vegas, NV.

Moulton, C.E., R.S. Brady, and R.J. Belthoff. 2005. A comparison of breeding season food habits of Burrowing Owls nesting in agricultural and nonagricultural habitat in Idaho. Journal of Raptor Research 39:429-438.

Muma, M.H. 1963. Solpugida of the Nevada Test Site. Brigham Young University Science Bulletin, Biological Series 3(2):1-13. 
National Security Technologies, LLC. 2007. Ecological Monitoring and Compliance Program 2006 Report. U.S. Department of Energy, National Nuclear Security Administration, Nevada Site Office Report DOE/ NV/25946-174, Las Vegas, NV.

Ostler, W.D., D.J. Hansen, D.C. Anderson, and D.B. HALL. 2000. Classification of vegetation on the Nevada Test Site. U.S. Department of Energy, Nevada Operations Office Report DOE/NV/11718477, Las Vegas, NV.

Plumpton, D.L., AND R.S. Lutz. 1993. Prey selection and food habits of Burrowing Owls in Colorado. Great Basin Naturalist 53:299-304.

Poulin, R.G., AND L.D. TodD. 2006. Sex and nest stage differences in the circadian foraging behaviors of nesting Burrowing Owls. Condor 108:856-864.

Rosenberg, D.K., and K.L. Haley. 2004. The ecology of Burrowing Owls in the agroecosystem of the Imperial Valley, California. Studies in Avian Biology 27:120 135.

SAethre, M.B. 1995. Small mammal populations on the Nevada Test Site, 1994. Pages 36-123 in R.B. Hunter, compiler, Status of the flora and fauna on the Nevada Test Site, 1993. Reynolds Electrical \& Engineering Co., Inc. Report DOE/NV/11432—162, Las Vegas, NV.

Smith, D.G., AND J.R. Murphy. 1973. Late summer food habits of adult Burrowing Owls in central Utah. Journal of Raptor Research 7:112-115.
Thomsen, L. 1971. Behavior and ecology of Burrowing Owls on the Oakland Municipal Airport. Condor 73:177-192.

Tyler, J.D. 1983. Notes on Burrowing Owl (Athene cunicularia) food habits in Oklahoma. Southwestern Naturalist 28:100-102.

U.S. Department of Energy. 1996. Final environmental impact statement for the Nevada Test Site and offsite locations in the state of Nevada. Volume 1, chapters 1-9. DOE/EIS 0243. Las Vegas, NV.

Verts, B.J., AND L.N. CarRaWAY. 1998. Land mammals of Oregon. University of California Press, Berkeley.

Wills, C.A., AND W.K. Ostler. 2001. Ecology of the Nevada Test Site: an annotated bibliography. U.S. Department of Energy, National Nuclear Security Administration, Nevada Operations Office Report DOE/NV/11718 - 594, Las Vegas, NV.

York, M., D.K. RosenberG, And K.K. Sturm. 2002. Diet and food-niche breadth of Burrowing Owls (Athene cunicularia) in the Imperial Valley, California. Western North American Naturalist 62:280-287.

Received 31 July 2007 Accepted 10 June 2008 